\title{
Effect of Aerobic Training on Blood Viscosity in Hypertensive Women
}

\author{
EMAN N. NAWARA, M.Sc.*; NESREEN ELNAHAS, Ph.D.*; ZAHRA HASSAN, Ph.D.* and \\ MAATHER KAMEL, M.D.**
}

The Departments of Physical Therapy for Cardiovascular/Respiratory Disorder and Geriatrics, Faculty of Physical Therapy, Cairo University* and Biochemistry, Faculty of Medicine, Menofeya University**

\begin{abstract}
Background: Blood viscosity level increases in hypertensive patients. Objective of this study was to determine the effect of aerobic training on blood viscosity in hypertensive women.

Aim of Study: To investigate effect of aerobic training on blood viscosity in hypertensive women.

Material and Methods: Thirty obese diabetic women participated in this study chosen from Al-Bagour public hospital in 2018. The patients were assigned into two equal groups. Each group included 15 patients. The patients in both groups were matched in age ranged from (50-65 years old) and body mass index ranged from ( 25 to $29.9 \mathrm{Kg} / \mathrm{m}^{2}$ ), with mild to moderate hypertension and had high blood viscosity $>4.5$ relative to water. All patientsreceived medications according to physician prescription, Group A received a program of aerobic training using treadmill 3 days/week for 8 weeks with intensity 60-80\% MHR started with 20 minutes and increased by 5 minutes every two weeks till reaching 40 minutes at 8 th week. Warm up phase 5-10 minutes, cool down phase 5-10 minutes in form of walking on treadmill at low speed.while group B acted as control group.
\end{abstract}

Results: The data revealed a statistically decrease in blood viscosity level in group A than in group B after treatment $(p<0.05)$

The percentage of improvement in group A was $20 \%$ while it was $7.2 \%$ in group B.

Conclusion: Aerobic training had valuable effect on blood viscosity level in women with hypertension.

Key Words: Aerobic training - Blood viscosity - Hypertension.

\section{Introduction}

HYPERTENSION is defined as a condition when subjects are on current antihypertensive medication and/or systolic blood pressure of more than or

Correspondence to: Dr. Eman N. Nawara, The Department of Physical Therapy for Cardiovascular/Respiratory Disorder and Geriatrics, Faculty of Physical Therapy, Cairo University equal to $140 \mathrm{mmHg}$ and/or diastolic blood pressure of more than or equal to $90 \mathrm{mmHg}$ [1]. Classified into two groups: Essential hypertension which affects $90 \%$ of cases but the primary abnormality that causes hypertension is unknown and secondary hypertension which affects the remaining $10 \%$ cases [2]. Hypertension is the most common condition seen in primary care and leads to myocardial infarction, Stroke, renal failure, and death if not detected early and treated appropriately [3]. Blood viscosity is a property of the fluidity and internal friction of blood determined in part by adjacent fluidy blood cells as well as other constituents sliding past one another. Increase in whole blood viscosity is subclinical risk factor for future cardiovascular disease [4]. Hyperviscosity is classically admitted to disturb blood flow and to represent a risk factor for the development of cardiovascular disease [5]. Aerobic exercises, such as walking and swimming, cause harder breathing and faster heart beating than occur at rest. Benefits of doing aerobic exercise include strengthening the heart and improving circulation, lowering blood pressure, and helping to control blood sugar and weigh [6]

Individuals who regularly undertake physical exercise show improvement in the haemorheological parameters of the blood involving reduction in blood viscosity as well as improvement in elastic properties of red blood cells, increase in tissue flow and the subsequent reduction in the risk of cardiovascular complications [7].

\section{Material and Methods}

\section{Subjects and study design:}

Thirty women was recruited for this study from Al-Bagour public hospital in El-Menofeya and out clinics in 2018, their age between 50 and 65 years old with mild to moderate hypertension controlled by anti-hypertensive drugs, Blood pressure was: 
Systole (140-179) mm Hg and diastole: (90-109) $\mathrm{mm} \mathrm{Hg}$, had high blood viscosity $>4.5$ relative to water and their body mass index ranged from $(25$ to 29.9$) \mathrm{kg} / \mathrm{m}^{2}$; they were assigned into two groups equally in number: Group A (study group) Fifteen patients participated in aerobic training program and received medications according to their physicians. Group B (Control group) Fifteen patients received medications according to their physicians prescription only.

\section{Aerobic training program:}

For group A (study group):

Mode of exercise: Treadmill. Intensity: 60-80\% MHR. Duration: Started with 20 minutes and increased by 5 minutes every two weeks till reaching 40 minutes at the 8 th week. Warm up phase 510minutes, cool down phase 5-10 minutes in form of walking on treadmill at low speed. Frequency: 3 days/week for 8 weeks.

\section{Analysis of data:}

Demographic data collected and represented as mean and SD for age, BMI for all patients.

Paired " $t$ " test was used to compare the results between before and after management period for the measured blood viscosity of significance of $(p<0.05)$. Unpaired " $t$ " test was used to compare the results between before and after management period for the measured lipoproteins level between both groups.

\section{Results}

\section{The physical characteristics of patients in both groups:}

Table (1) represent the mean and standard deviation (S.D) of physical characteristics of all patients in both groups $(A \& B)$, The age of patients in the group (A), ranged from 50 to 65 years with a mean value of (56.66 \pm 5.16 years), the BMI ranged from 25 to 29.9 with mean value of $(27.3 \pm 1.32 \mathrm{~kg}$ $/ \mathrm{m}^{2}$ ). And, the age of patients in the group (B), ranged from 50 to 65 years with a mean value of (57.13 \pm 4.73 years), the BMI ranged from 25 to 29.9 with a mean value of $\left(27.23 \pm 1.41 \mathrm{~kg} / \mathrm{m}^{2}\right)$. The differences concerning age, BMI between women of both groups (A\&B) before starting the study were found to be statistically non-significant $(p>0.05)$.

The mean \pm SD blood viscosity pre treatment of group A was 5.6 \pm 0.94 relative to water and that of group B was $5.41 \pm 0.79$ relative to water. The mean difference between both groups was 0.19 relative to water. There was no significant difference in the blood viscosity between group A and B pre treatment $(p=0.54)$. The mean \pm SD blood viscosity post treatment of group A was $4.48 \pm 0.55$ relative to water and that of group B was $5.02 \pm 0.64$ relative to water. The mean difference between both groups was -0.54 relative to water. There was a significant decrease in the blood viscosity of group A compared with that of group B post treatment.

Table (1): Demographic features of both groups.

\begin{tabular}{|c|c|c|c|c|c|c|}
\hline & Group A & Group B & \multirow{2}{*}{ MD } & \multirow{2}{*}{$\begin{array}{c}t- \\
\text { value }\end{array}$} & \multirow{2}{*}{$\begin{array}{c}p- \\
\text { value }\end{array}$} & \multirow{2}{*}{ Sig. } \\
\hline & $\mathrm{X} \pm \mathrm{SD}$ & $\mathrm{X} \pm \mathrm{SD}$ & & & & \\
\hline Age (years) & $56.66 \pm 5.16$ & $57.13 \pm 4.73$ & -0.47 & -0.25 & 0.79 & NS \\
\hline BMI $\left(\mathrm{kg} / \mathrm{m}^{2}\right)$ & $27.3 \pm 1.32$ & $27.23 \pm 1.41$ & 0.07 & 0.14 & 0.88 & NS \\
\hline $\begin{array}{ll}\mathrm{X} & \text { Mean } \\
t \text {-value } & \text { Unpa } \\
\mathrm{MD} & \text { : Mean } \\
\mathrm{S} & \text { : Signi }\end{array}$ & $\begin{array}{l}\text { red t-value. } \\
\text { difference. } \\
\text { icant. }\end{array}$ & & $\begin{array}{l}\text { SD } \\
\text { o-valu } \\
\text { t-value : } \\
\text { NS }\end{array}$ & $\begin{array}{l}\text { Standa } \\
\text { Probab } \\
\text { Paired } \\
\text { Non sig }\end{array}$ & $\begin{array}{l}\text { lity val } \\
\text { tvalue. } \\
\text { nificant }\end{array}$ & on. \\
\hline
\end{tabular}

Table (2): Comparison between pre and post treatment mean values of blood viscosity of group A and B.

\begin{tabular}{lcccccc}
\hline Group A & $\begin{array}{c}\text { Blood viscosity } \\
\text { (relative to water) }\end{array}$ & \begin{tabular}{c}
$\%$ of \\
\cline { 2 - 5 } MD change
\end{tabular} & $\begin{array}{c}t \text { - } \\
\text { value }\end{array}$ & $\begin{array}{c}p \text { - } \\
\text { value }\end{array}$ & Sig. \\
\hline Pre & $5.6 \pm 0.94$ & 1.12 & 20 & 3.96 & 0.001 & $\mathrm{~S}$ \\
Group B & & 0.39 & 7.2 & 2.61 & 0.02 & $\mathrm{~S}$ \\
Pre & $5.41 \pm 0.79$ & & & & & \\
Post & $5.02 \pm 0.64$ & & & & & \\
MD & -0.54 & & & & & \\
$t$-value & -2.49 & & & & & \\
$p$-value & 0.01 & & & & & \\
\hline
\end{tabular}

\section{Discussion}

The finding of this study showed that aerobic training had a valuable effect to reduce blood viscosity in patients with hypertension.

The present study revealed that: The percentage of improvement in blood viscosity in Group A (Study group) after treatment was high significantly decreased by $20 \%$ while in Group B (Control Group) decreased by $7.2 \%$ which was nonsignificant. These findings support the results of studies performed by Antunes et al., [8] who observed decrease in blood viscosity among participants in the experimental group who follows a physical fitness program. It is coincided with Hamedinia et al., [9] who demonstrated that aerobic training can increase plasma volume, this agreement recovers blood viscosity, and it is consistent with Barbara et al., [10] who demonstrated that Regular physical training improved the exercise tolerability of patients with ischemic heart disease and decreased hematocrit and blood viscosity which reduce cardiovascular risk. In a study done by 
Abdeen et al., [11] thefindings show that high intensity interval training for 12 weeks promotes the reduction of risk factors of cardiovascular disease in postmenopausal hypertevsivewomen. It is coincided with Nikam et al., [12] who indicated that regular physical exercise protects cardiovasaular system by modulating lipid profiles. In contrast with Bobeuf et al., [13] who indicated that after 6 months of resistance training there was no change in hematocrit, red blood cell count or plasma volume which are all implicated in blood viscosity on older women and men. This study disagreed with Philippe Connes [14] who demonstrated that exercise induces important hematological / hemorheological changes such as an increase of hematocritand blood viscosity. Inspite of the study of HeimoMairbäurl [15] who observed that exercise and training increase whole blood viscosity during exercise which reverses rapidly due to hemoconcentration and dehydration.

\section{Conclusion:}

Aerobic training had a role in management of blood viscosity in hypertensive women.

\section{Future perspectives:}

It is recommended to perform an aerobic training program for management of hypertension and to check blood viscosity level to overcome its complication. Further researches should focus on investigating the effect of Aerobic training on blood viscosity in diabetic women.

\section{References}

1- BLACK H.R., SICA D., FERDINAND K. and WHITE W.B.: American Heart Association E, Arrhythmias Committee of Council on Clinical Cardiology CoCDiYCoC, Stroke Nursing CoFG, Translational B, American College of C. Eligibility and disqualification recommendations for competitive athletes with cardiovascular abnormalities., Task force 6: Hypertension: A scientific statementfrom the american heart association and the american college of cardiology. Circulation, 132: e298-302, 2015.

2- ANDREA S.H.: Acute and chronic effect of aerobic and resistance exercises on ambulatory blood pressure in hypertensive patients, Institute of Physiology and Anatomy German Sport University Cologne, 2011.

3- ANA PAULA CABRAL DE FARI GUSTAVO HENRIQUE OLIVEIRA-PAULA PAMELA SOUZA SILVAN CELSO BIAGI JOSE EDUARDO TANUS-SANTOS and HEITOR MORENO.: Effects Of Angiotensin-Converting
Enzyme Inhibition on Leptin and Adiponectin Levels in Essential Hypertension, 2014.

4- EZCKICL U.: Whole blood viscosity assessment issues North American Journal, 2: 165-169, 2010.

5- FORCONI S. and GORI T.: The evolution of the meaning of bloodhyperviscosity in cardiovascular physiopathology: Should we reinterpret Poiseuille?, Clin. Hemorheol. Microcirc., 42: 1-6, 2009.

6- ANGELA J. BUSCH, CANDICE L. SCHACHTER, TOM J. OVEREND, SOO Y KIM, SUELEN M. GÓES, CATHERINE BODEN, HEATHER J.A. FOULDS and JULIA BIDONDE.: Aerobic exercise training for adults with fibromyalgia: CD012700, 2017.

7- ANNA MARCHEWKA, KATARZYNA FILARMIERZWA and ANETA TELEGL'ÓW.: Rheological blood properities versus physical exertion in the process of ageing, 13 (1): 19-22, 2009.

8- ANTUNES H.K., DE MELLO M.T., SANTOSGALDURÓZ R.F., GALDURÓZ J.C.F., AQUINOLEMOS V., TUFIK and BUENO O.F.A.: Effects of a physical fitness program on memory and blood viscosity in sedentary elderly men., 48 (9): 805-812, 2015.

9- HAMEDINIA M., HAGHIGHIA and RAVASI A.: Effect of aerobic training on inflammatory markers of cardiovascular disease risk in obese men world journal of sport sciences, 2 (1): 7-12, 2009.

10-BARBARA SANDOR, ALEXANDRA NAGY, ANDRASTOTH, MIKLOS RABAI, BELA MEZEY, ARPAD CSATHO, ISTVAN CZURIGA, KALMAN TOTH, and ESZTER SZABADOS: Effects of Moderate Aerobic Exercise Training on Hemorheological and Laboratory Parameters in Ischemic Heart Disease Patients, 9 (10): e110751, 2014.

11- ABDEEN H.A., ELNAHAS E.M. and ABDALLAH G.A: Impact of High Intensity Interval Versus Modrate Intensity Continuous Training on Modulating Cardiovascular Disease Risk factor in postmenopasal women, Vol. 5, No. 5 pp. 2405-19, 2017.

12-NIKAM, JOSHI,VIVEKI and HALAPPANAVAR: Effect of regular physical exercise on lipid profile, lipid peroxidation and enzymatic antioxidants: International journal of biochemistry research and review. Vol., 3, No. 4: pp. 414-20, 2013

13- BOBEUF, LABONTE KHALIl and ISABELLE: Effect of Resistance training on hematological blood markers in older men and women: A Pilot Study, (12): 114-117, 2009.

14- PHILIPPE CONNES: Elevated blood viscosity during exercise: What are the consequences? Clinical Hemorheology and Microcirculation, 42: 303-304, 2009.

15- HEIMO MAIRBÄURL: Red blood cells in sports: Effects of exercise and training on oxygen supply by red blood cells, 4: 332, 2013. 


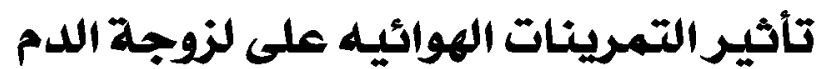

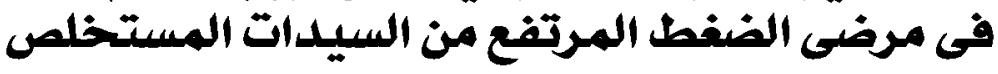

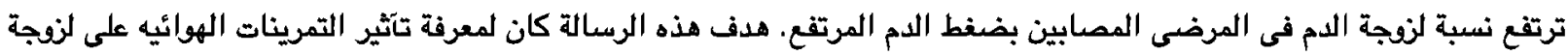

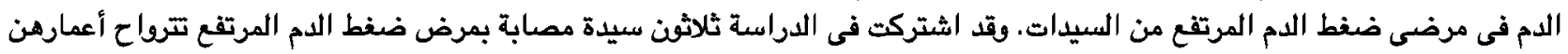

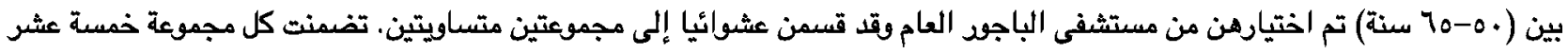

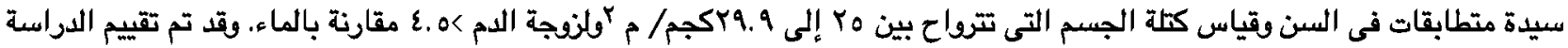

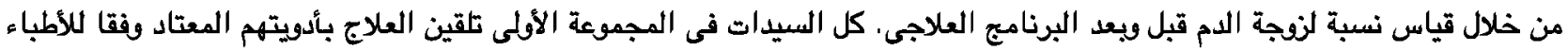

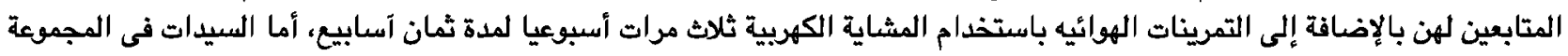

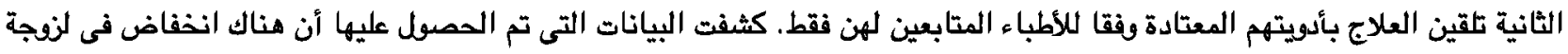

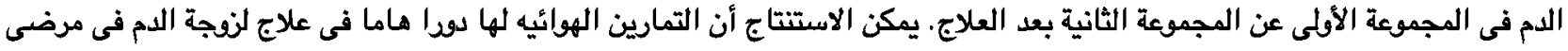
الضغط المرتفع من السيدات. 